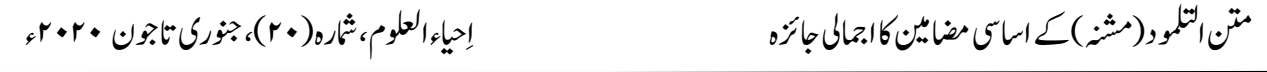

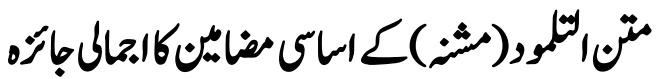

\section{An Overview of Fundamental Articles in Talmūd (Mishnā)}

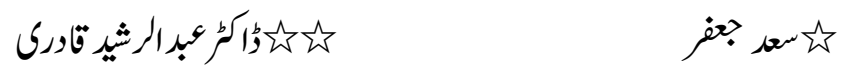

\section{Abstract:}

Among the Jews, The Old Testament has the same status as the status of The Holy Qur'an for the Muslims. According to the Jews, God gave Moses (AS) the Bible as a scripture and also gave him another oral law. The oral law is passed down from generation to generation through the elders and the oral law is definite and obligatory for the Jews. The Jewish scholars believe that oral law provides the complete interpretation of Jewish shari'ah. This oral law was handed over to Yūsha' bin Nün by Moses (AS), its initial script is called Mishnā which was published in 70 CE. The description of Mishnā is called Gemārā which was published in 200 CE. The combination of script (Mishnā) and its description (Gemārā) is called Talmud which was published in 400 to 500 CE. Talmud is considered to be the most authoritative text for the Jews. This article will give a brief overview of all volumes of Mishnā. These volumes include Zerēm (order of seeds), Mo id (festivals), Nashīm (Women), Nazīkīn (demages), Kedāshìm (holy ones), and Tohürat (purities). This article will provide enough discussions in making researchers understand the theme of Talmud.

Key words: Jews, Oral law, Mishnā, Gemārā, Talmud.

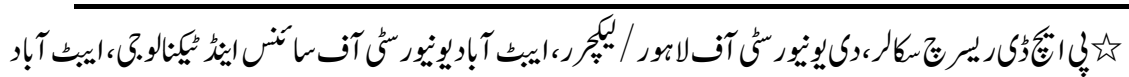

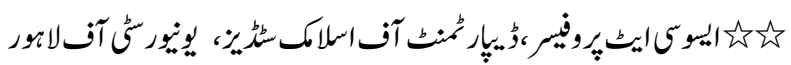




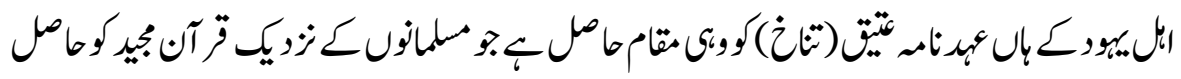

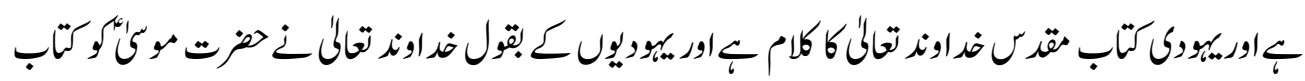

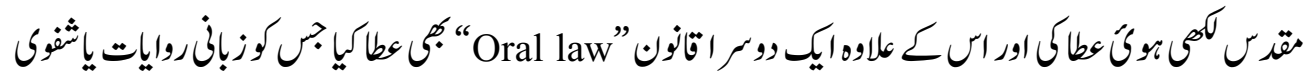

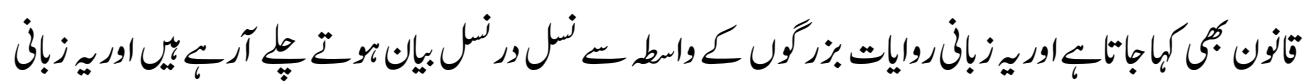

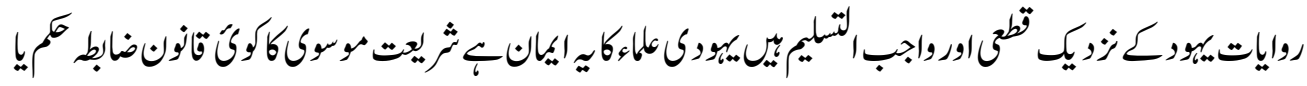

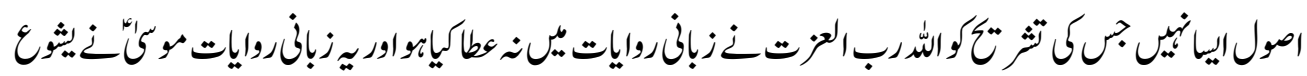

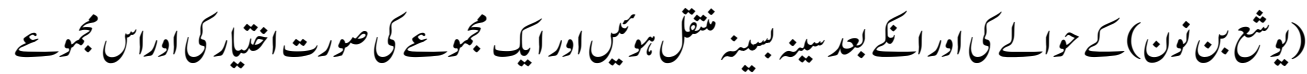

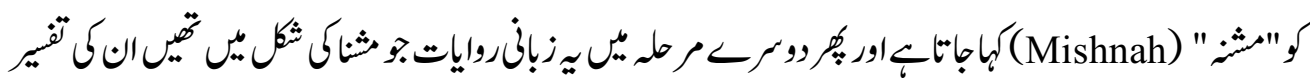

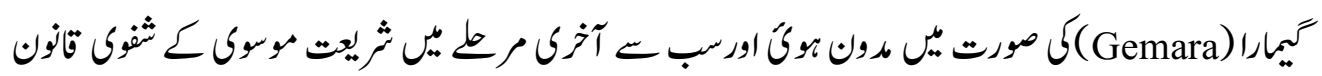

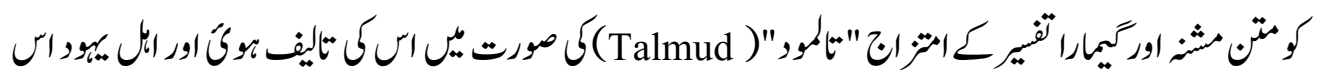

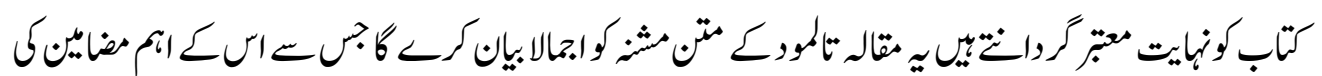

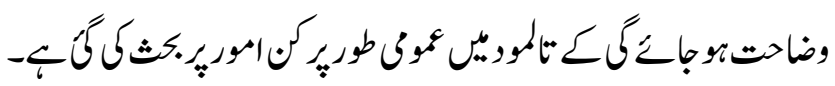

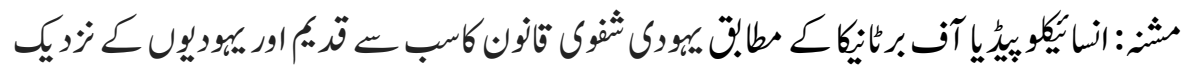

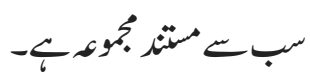

"Oldest authoritative collection of Jewish oral law, supplementing the written laws in the Hebrew Scriptures. It was compiled by a series of scholars over two centuries and was given final form in the 3rd century AD by JUDAH HANASI"1

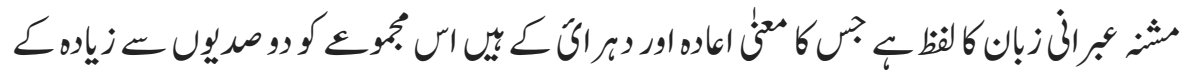

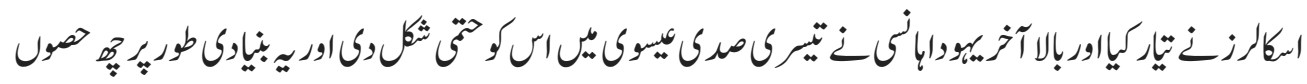

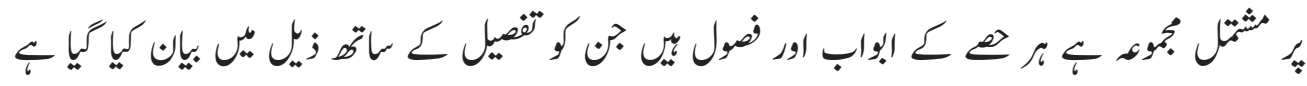

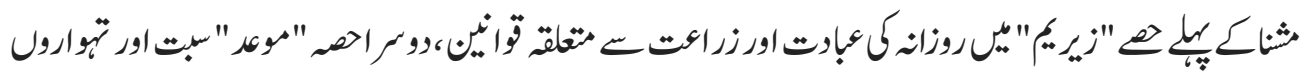

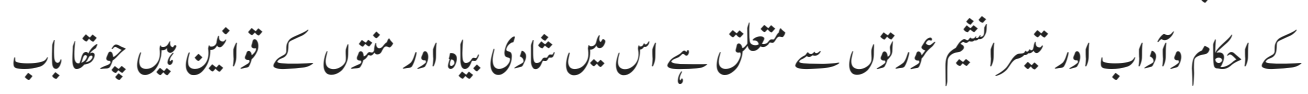




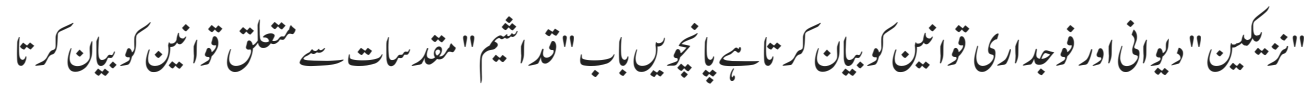

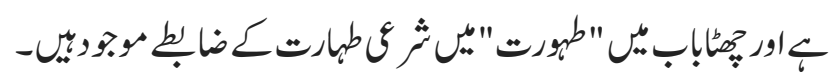

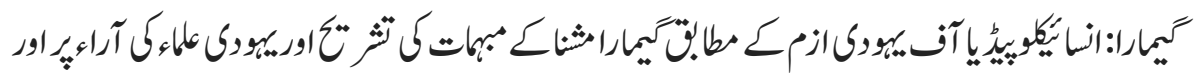

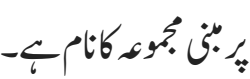

"Commentaries and debates among the ancient rabbis concerning the contents of the Mishnah were compiled to create the Gemara" ${ }^{2}$

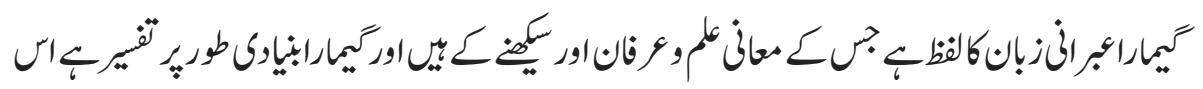

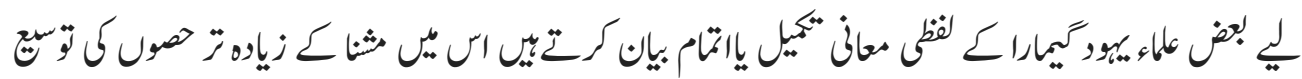

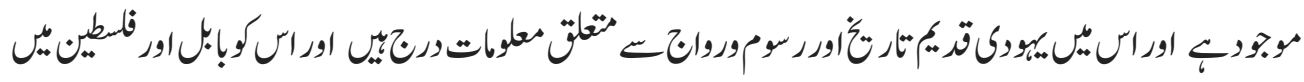

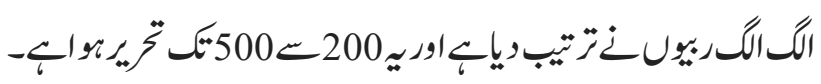

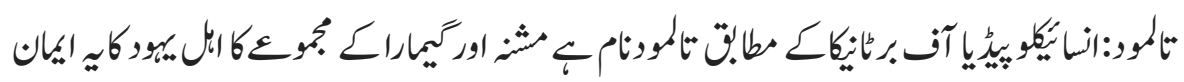

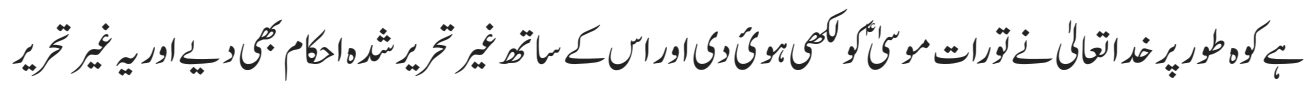

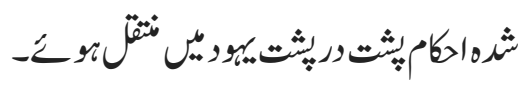

"In JUDAISM, the systematic amplification and analysis of passages of the MISHNA, the GEMARA, and other oral law, including the TOSEFTA. Two Talmud's exist, produced by two different groups of Jewish scholars: the Babylonian Talmud (c. AD 600) and the Palestinian Talmud (c. AD 400). The Babylonian Talmud is more extensive and thus more highly esteemed ${ }^{3 n}$

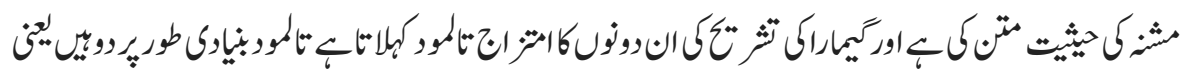

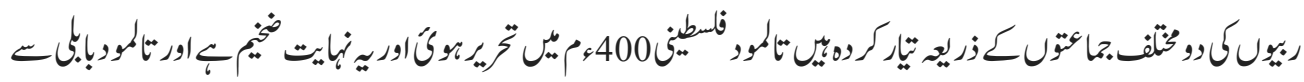

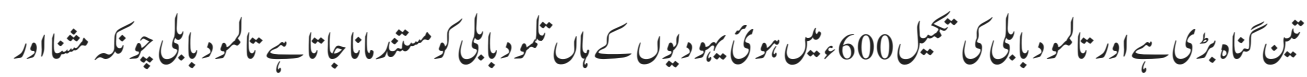

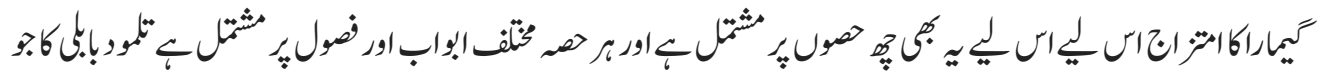

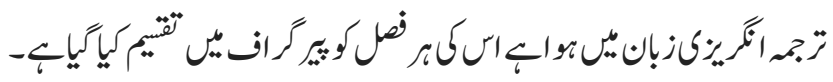




$$
\begin{aligned}
& \text { 1-زيريم (نقيجاتم) }
\end{aligned}
$$

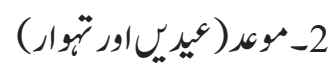

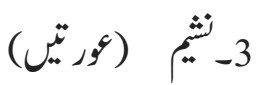

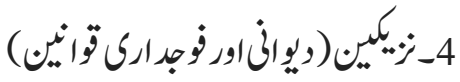

$$
\begin{aligned}
& \text { 5ـقراشيم(مقدات) }
\end{aligned}
$$

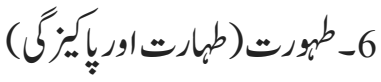

(Oder of seeds) زير Zeraim-1

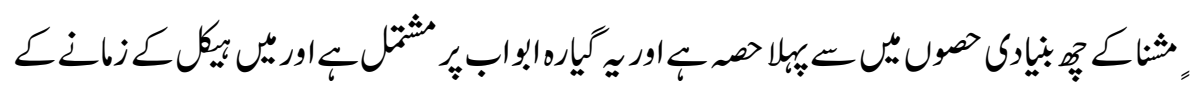

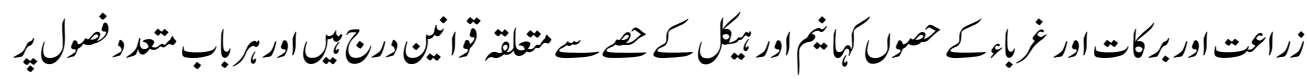

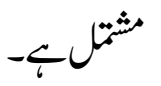

"Section Zeraim (Plants) contains eleven tractates, eleven.: Berakhot, supplied with Gemara, both Palestinian and Babylonian, Peah , Dmai , Khilayim, Shebüt, Therumoth, Maasheroth, MaaserSheni, Chala, Orla (Fruit trees during the first three years), and Biccurim (First fruit)"4

\section{(Blessings)براخوت :البركاتوران:Berakhot_1}

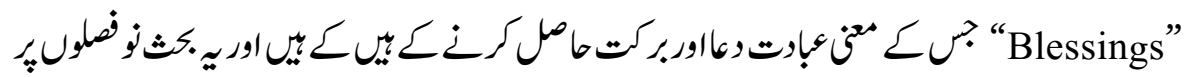

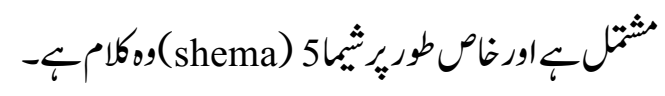

"R. Abuha said: "Jerusalem was not destroyed until they had abolished the reading of the Shema in the morning and in the evening"6

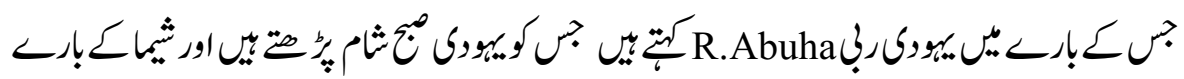

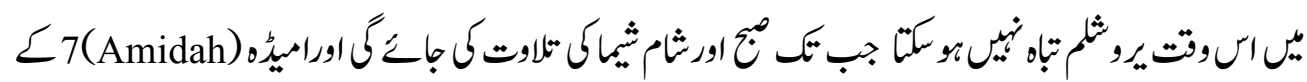

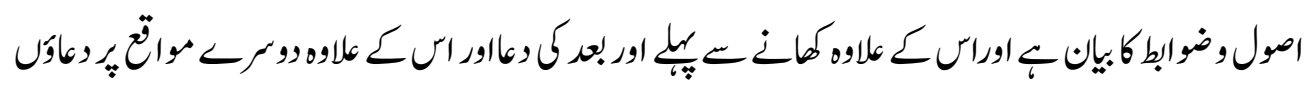

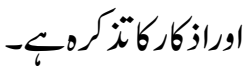




\section{(نيمياه:Pe'ah_2}

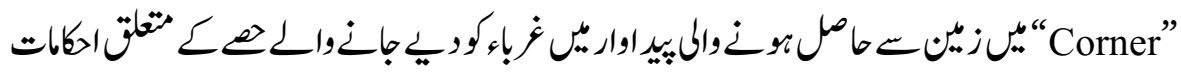

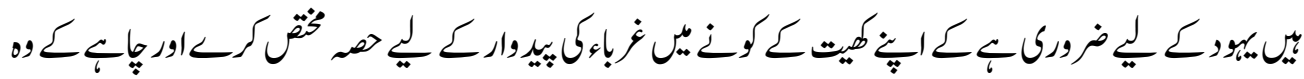

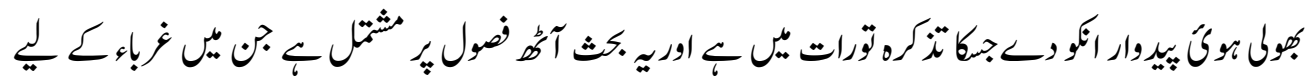

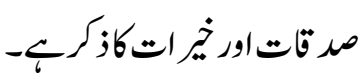

"Peah signifies the comers of the field, the crops of which must be left over for the widows, orphans, etc" 8

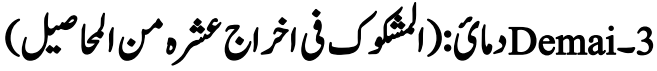

". Doubtfully Tithed Produce”

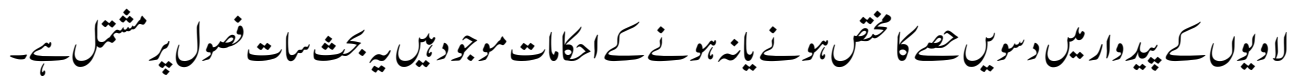
"Tithing is a biblical principle by which the ISRAELITES set aside a portion of their produce for certain disadvantaged groups as an offering to God. The major tithing was 10 percent of one's produce." 9

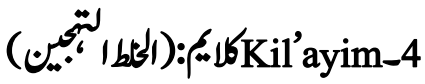

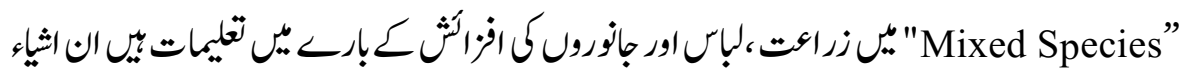

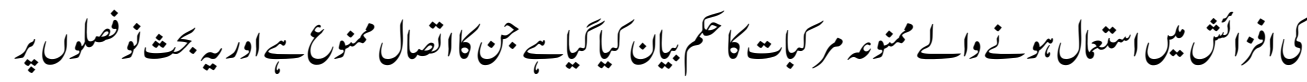

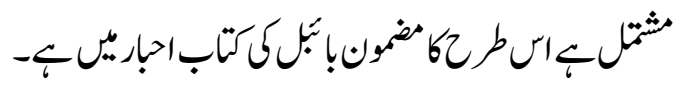

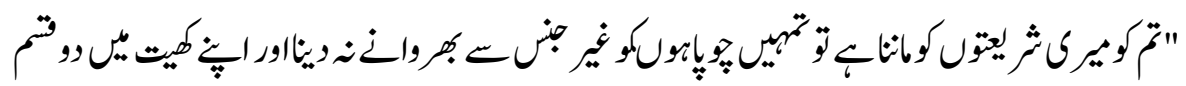

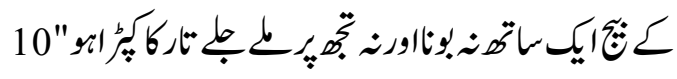

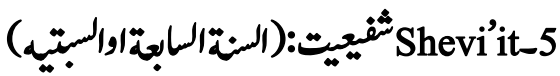

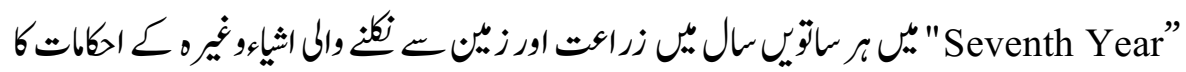

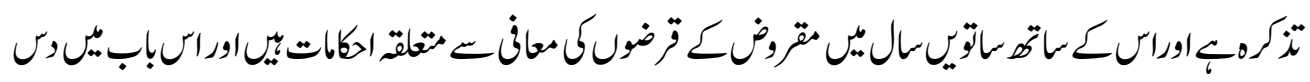

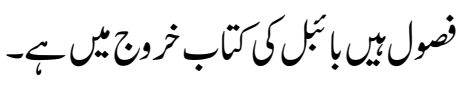




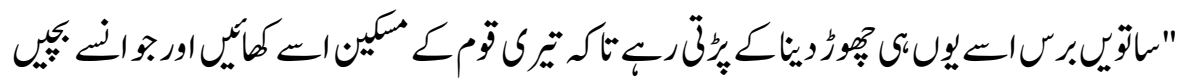

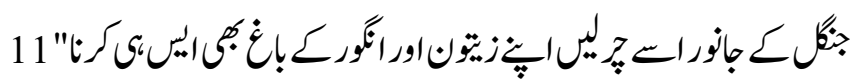
Terumot-6

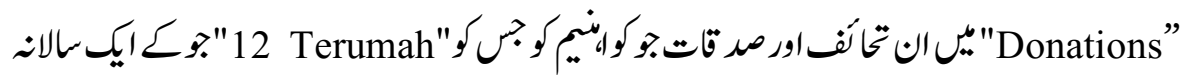

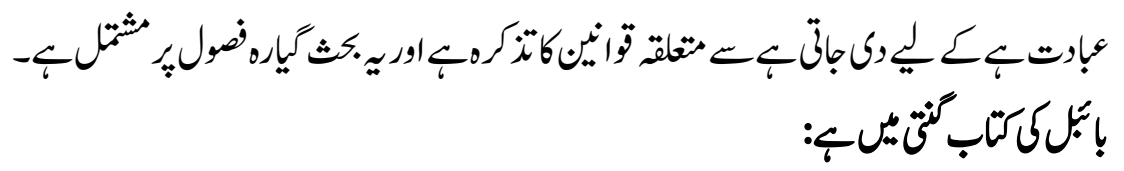

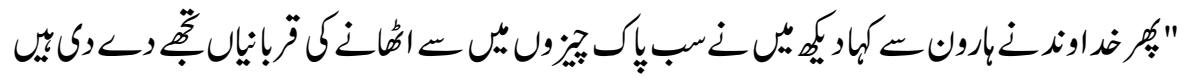

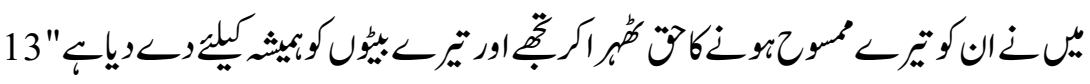

$$
\begin{aligned}
& \text { Maaserot_7 }
\end{aligned}
$$

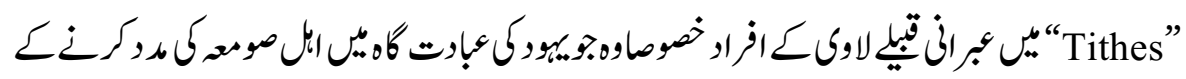

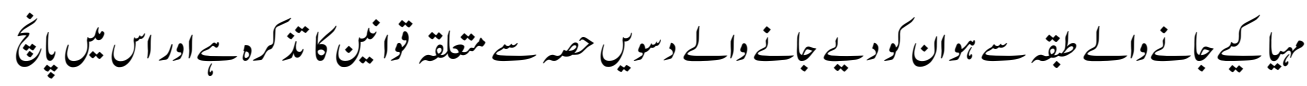
ضولبيك-

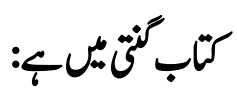

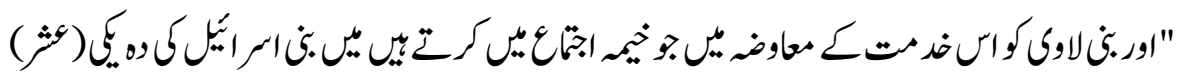

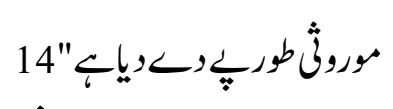

\section{Ma'aser Sheni-8}

"Second Tithe"

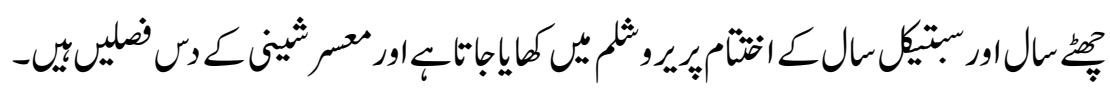

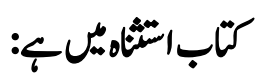

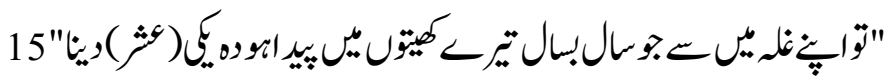

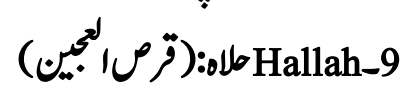

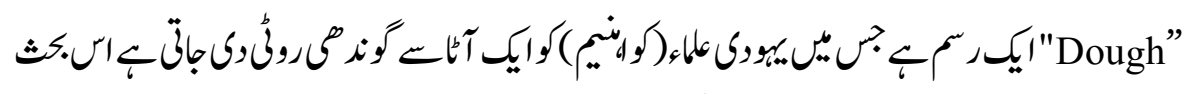

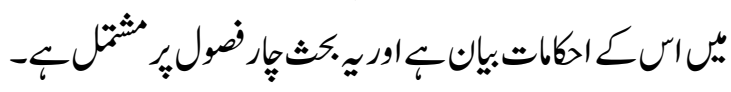


"The rules for taking the priest's share from any dough in ritual purity" 16

(الزلة)Orlah-10

First Fruits of Trees"

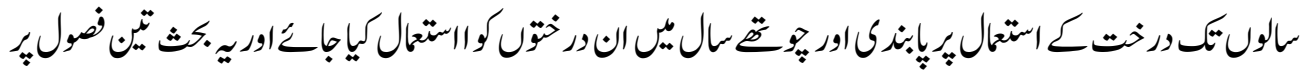<smiles>[CH-][CH-][CH-]</smiles>

"The rules for treating a fruit tree the first three years after its planting when its fruit may not be eaten" 17

\section{(بوريم (بواكير الثمار):Bikkurim-11}

9. "First Fruits"

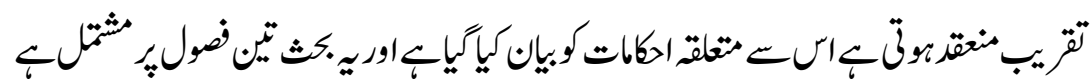

"The rules of designating first fruits for dedication to the Temple and the ceremonies of their presentation in the Temple"18

$$
\begin{aligned}
& \text { موعد:Mo'ed(المواسموالاعيار) }
\end{aligned}
$$

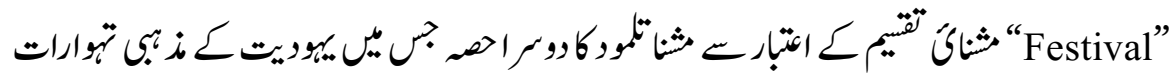

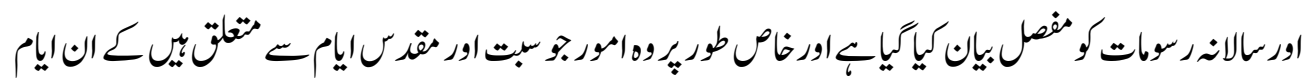

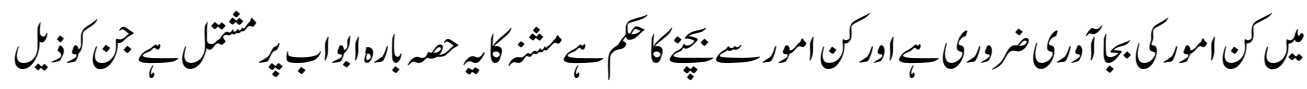

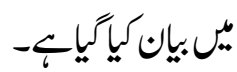

"Moed (Festivals), containing the following tracts: Sabbath, Erubhin, Rosh Hashana, Yuma, Shekalim, Sukkah, Megillah, Taanith, Pesachim, Betzah, Hagigah, and Moed Katan. All these tracts areentirely devoted to precepts pertaining to the observance of the festivals and Sabbath, such as the performance of the different ritual ceremonies on feastdays"19 


\section{Shabbat-1}

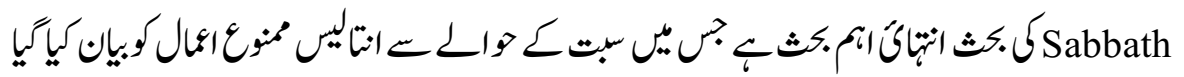

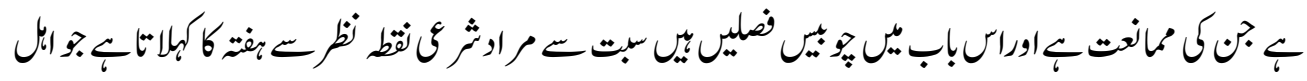

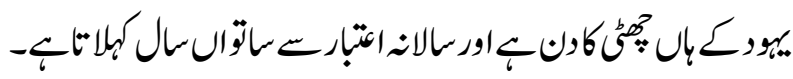

"Shabbat is the HEBREW term for Sabbath. Jewish law stipulates that from sunset on Friday night until nightfall on Saturday, Jews are remember and observe the Shabbat. The general rabbinic notion is that "observing" the Sabbath refers to the laws concerning prohibited activity on Shabbat"20

\section{Eruvin-2}

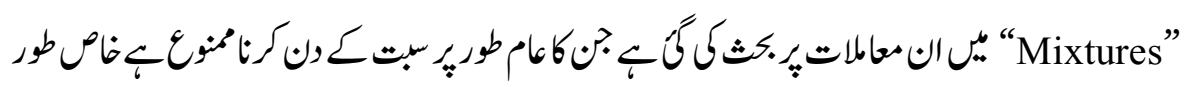

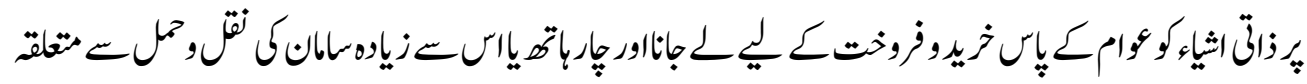

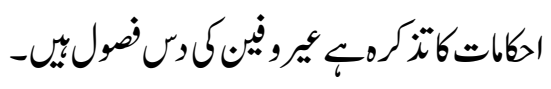

"An eruv is a ritual enclosure around a town or neighborhood that creates a common area, within which observant Jews may carry objects on SHABBAT"21

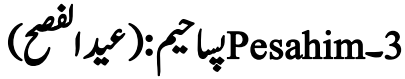

“" Passover Festivals”

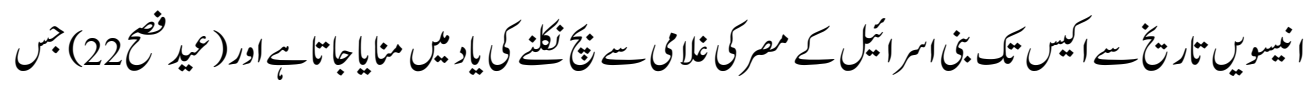

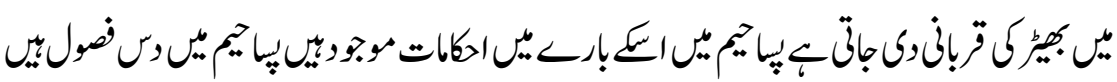
Shekalim_4

"Shekels”

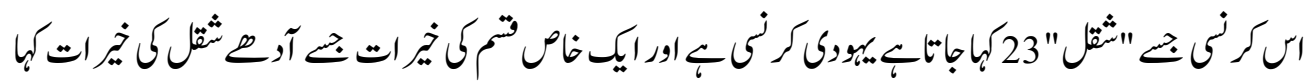

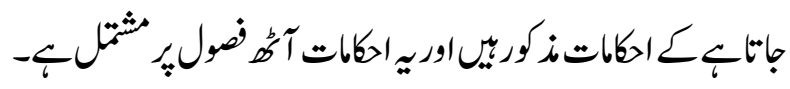


(يويام):Yoma-5

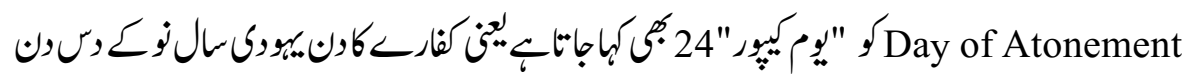

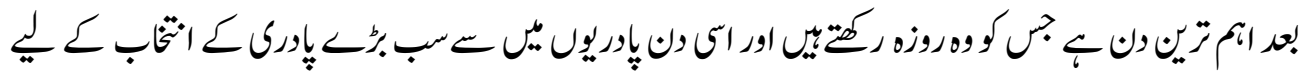

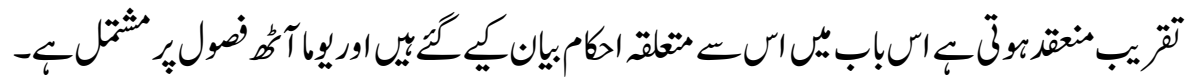

(المغلي):Sukkah_6

"Booth"

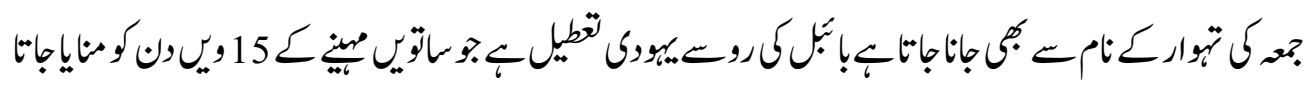

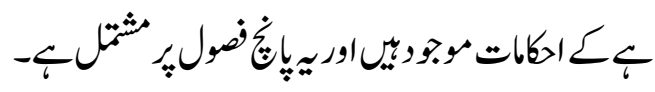

(البينيز):Beitza-7

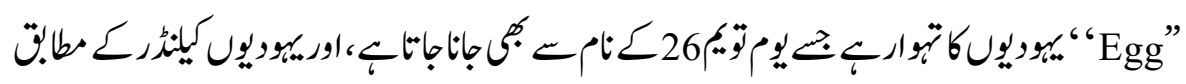

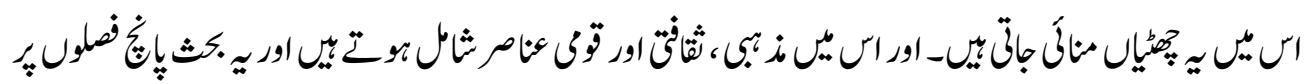

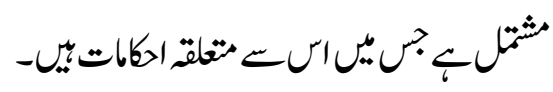

\section{Rosh Hashanah -8}

"New year" ان.كثيل

"Literally, Rosh HaShanah means the "head" of theyear. It falls on the first day of the Hebrew month of Tishri. Despite the fact that the Hebrew Biblerefers to Tishri as the seventh month of the Jewish CALENDAR, the first of Tishri has been celebrated since ancient times as the Jewish New Year."27

تنيت (الصيام) Ta'anit-9

“ت “Fasting”

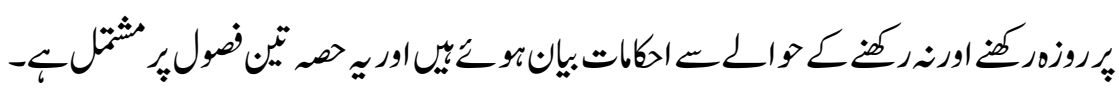

"A chronicle enumerating thirty-five eventful days in the history of the Jewish people on which fasting is forbidden" 28 
(اللفافة:Megillah-10

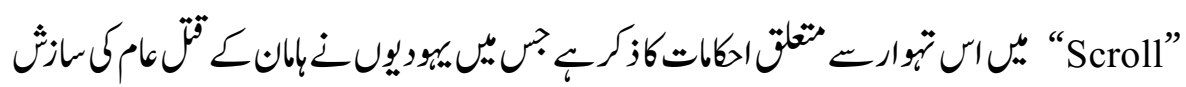

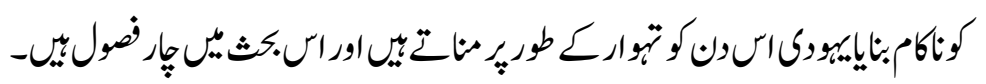

"On Purim, Jews read the MEGILLAH (scroll of)Esther in SYNAGOGUES and celebrate avidly. They give gifts of food and charity, known as MISHLOACH MANOT, dress in costumes, get drunk, and put on satirical plays known as Purimspiels"29

موعير قطان(الدير الصني) Mo'ed Katan-11

“ “ittle Festival”

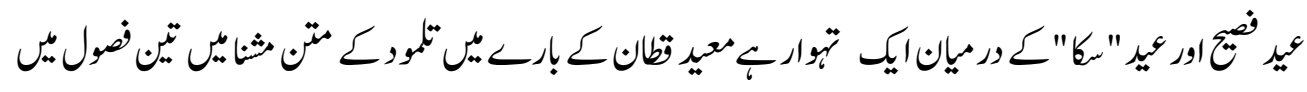

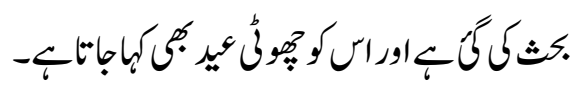

"Moed Katan (Minor Festivals) of the middle days between the first and seventh days of Passover and between the first and eighth days of Tabernacles" 30

\section{Hagigah-12}

“Festival Offering”

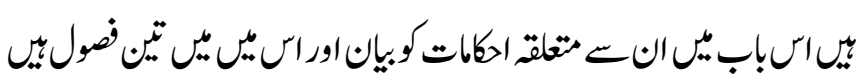

"The hagigah, an optional peace-offering brought by individuals in honour of the festival, usually on the first day ofthe festival"31

\section{(ن) Nashim}

"Women”

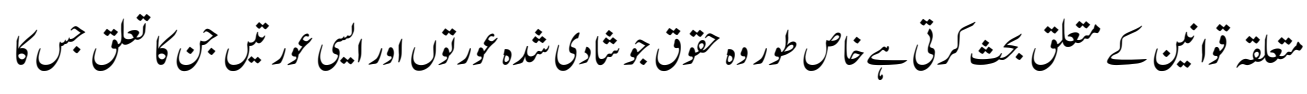

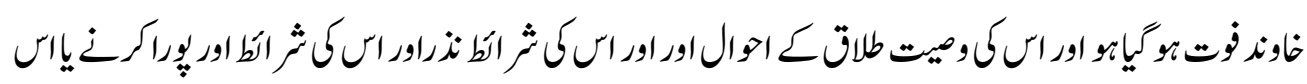

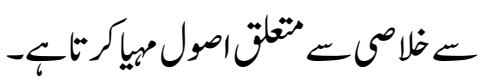


"Nashim, "Women," withseven tractates, which treats issues of married life, divorce, and other topics of the family and home"32

\section{يثياموت:(الاراط) Yevamot_1}

之ئ "Brothers-in-Law”

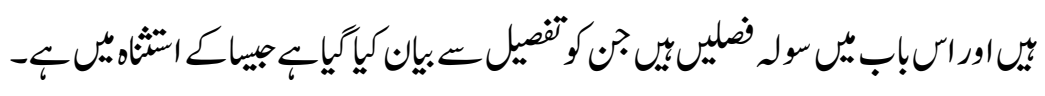

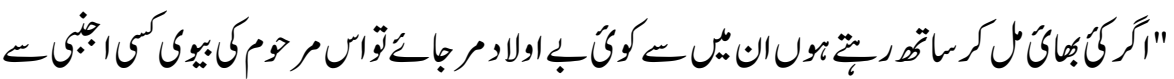

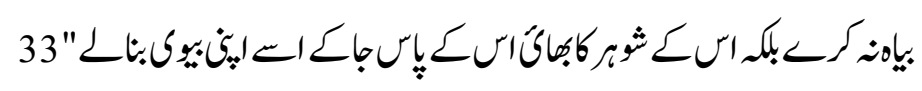

Ketubot-2

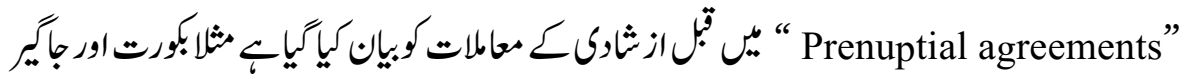

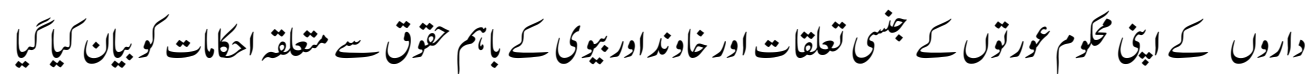

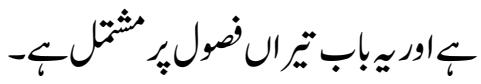

"The ketubah traditionally recorded the groom'sfinancial obligations toward his bride. It is written in ARAMAIC, the vernacular of Jews in ancienttimes, and follows a precise legal formula as prescribed by the TALMUD" 34

ندedarim-3

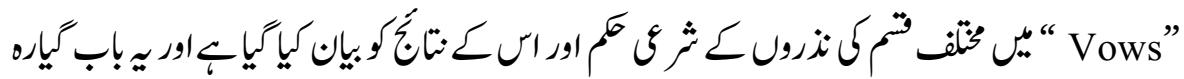

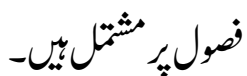

"According to the Book of Numbers (كتنى) any vow made by swearing an oath using any of the names of GOD must be fulfilled. The rabbis of the TALMUD debated whether it was appropriate to take any vows at all, given that they could lead to the violation of a serious commandment"35

\section{النير:(النامك)Nazir_4}

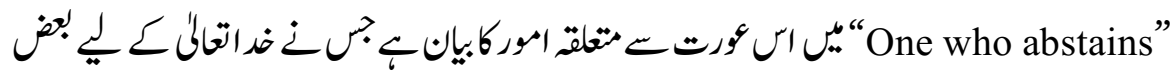

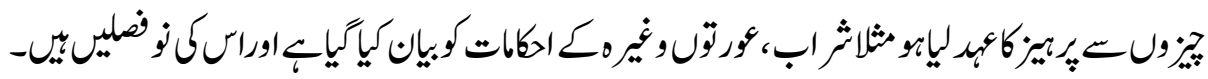




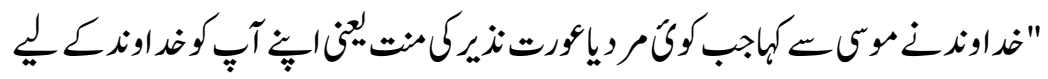

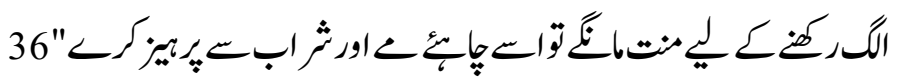

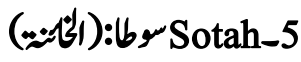

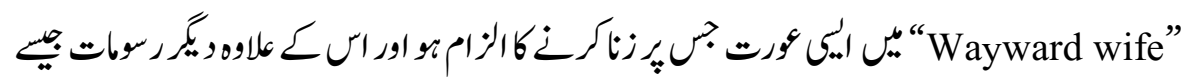

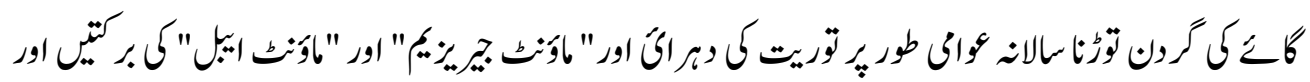

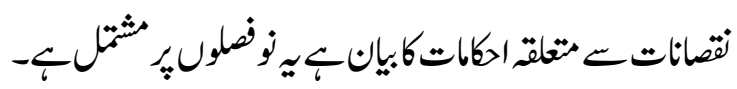

"Women suspected of illicit intercourse with strangers after they had been warned by their husband" 37

\section{Gittin-6}

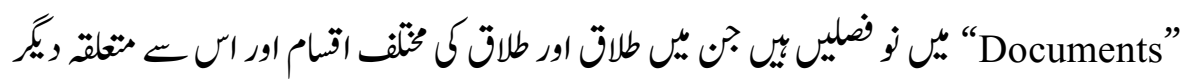

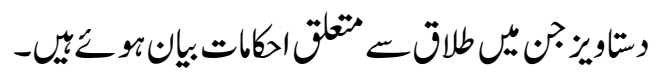

"A get is the official document that marks the rabbinic sanction of a DIVORCE. One tractate of the Talmud, Gittin, directly addresses the subject of divorce and the correct legal procedures for writing and delivering the get." 38

\section{(يّروشيُن:(الخطبة) Kiddushin-7}

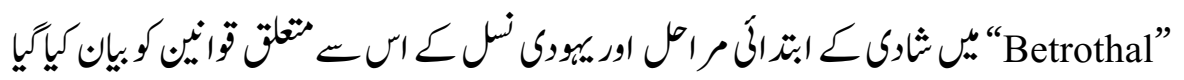

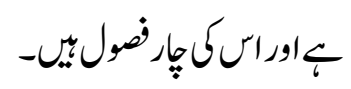

"In betrothal, the man gives the woman an object of value, in the presence of witnesses and recites, "You are hereby betrothed unto me in accordance with the law of Moses and Israel." A betrothal may be broken and the marriage called off only with a GET, a formal divorce decree decree"39

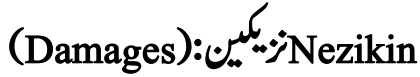

$$
\begin{aligned}
& \text { “Damages” }
\end{aligned}
$$

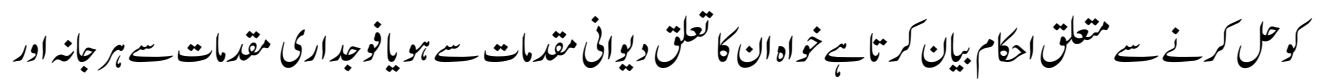

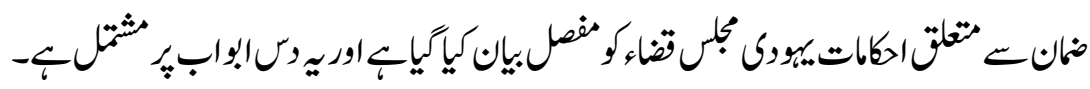


"Nezikin "Damages," with 10 tractates, which deals with criminal law, the court system, and punishment" 40

เo!̣!Bava kama-1

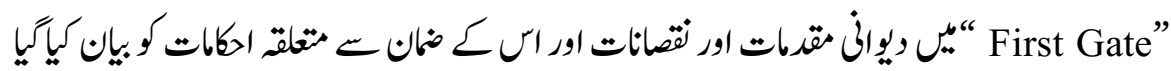

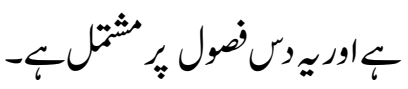

"The Bava Kamma deal mostly with damage laws generally answering two questions: when is a person obligated to pay damages that he or his property caused another person or his property" 41

Bava Metzia_2

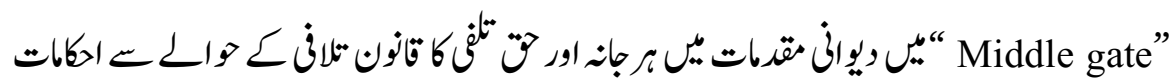

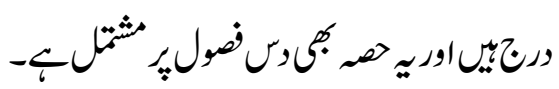

"Bava Metzia deal with cases where two people both claim ownership over an object which they are jointly holding" 42

Bava batra-3

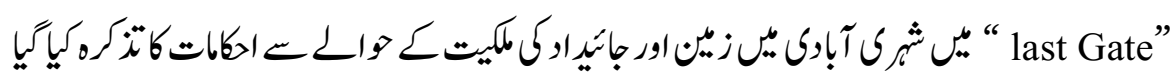

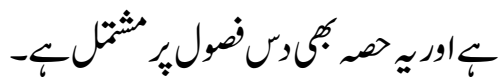

"Bava Batra deal with the laws of inheritance, the subject discussed in chapter eight." 43

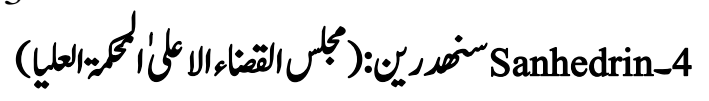

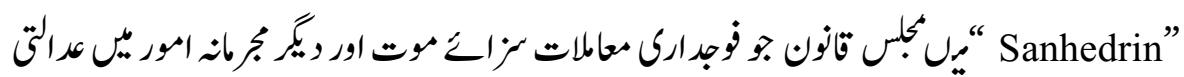

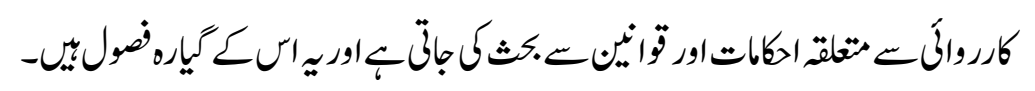

"Cases concerning monetary law and. Cases concerning robbery and personal injury and concerning damage that one is responsible for because he or his property caused the damage" 44

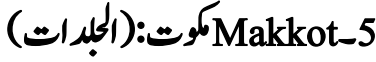

"Lashes"

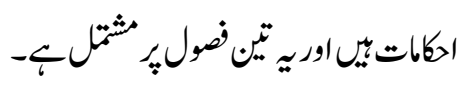


"The order of Makkot and discusses collusive witnesses, cities of refuge and the punishment of lashes" 45

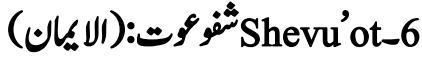

“ “مaths”

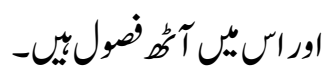

"The order of shevuot discusses varios types of Oaths and their consequences" 46

\section{Eduyot_7}

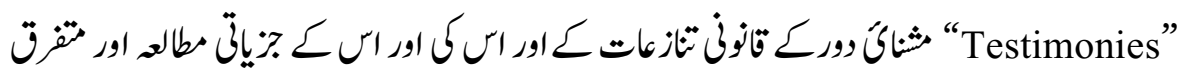

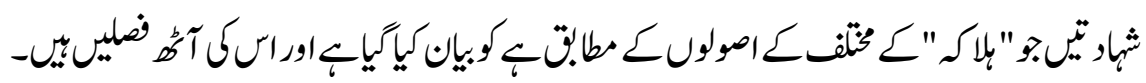

"The order of Eduyot presents the case studies of legal disputes in the light of principles of halakha"47

\section{Avodah Zarah-8}

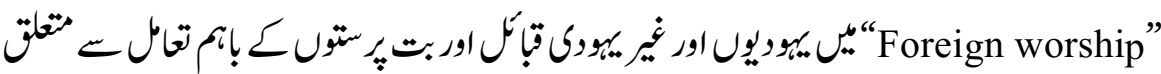

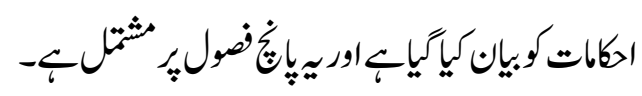

"The oder of Avodah Zarah describe the law of interactions between Jews and Gentiles, idolaters from Jewish perspective" 48

(آنوتش:(آلاء)

ف "Fathers”

"Avot, or Ethics of the Fathers, which deals primarily with

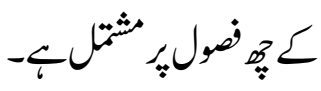
ethical behavior. It is a collection of philosophical and ethical sayings of the TANNAIM"49

$$
\text { Horayot-10 }
$$

تصن "Decisions” 
"The horayot describe and discusses major errors by the Sanhedrin"50

\section{( Holiness) قراشم :المقداتKodashim}

“Holiness”

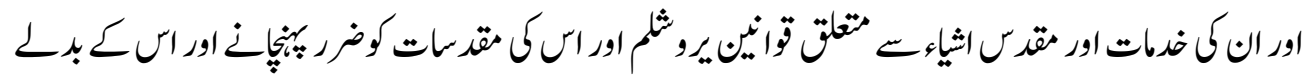

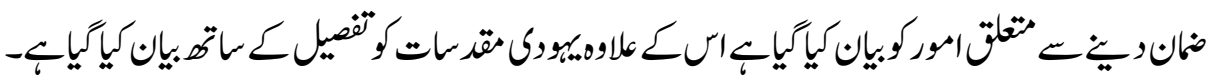
"Kodashim, concerning the TEMPLE in JERUSALEM and its rituals"51

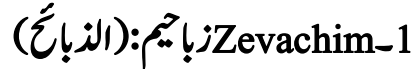

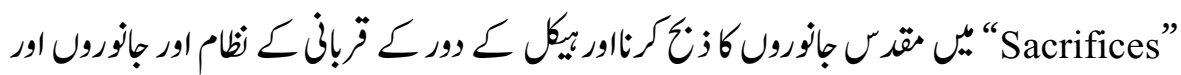

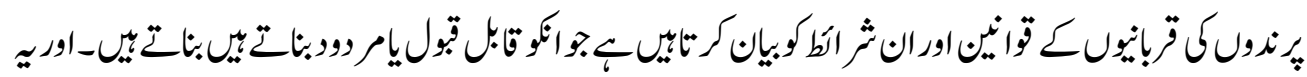

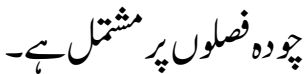

"Zevachim describe the procedure of animals and bird offering"52

\section{Menachot_2}

“Meal Offerings”

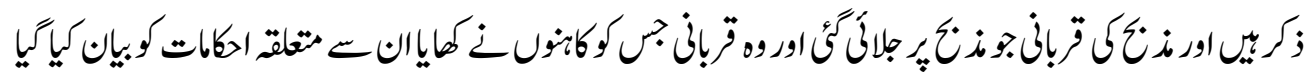

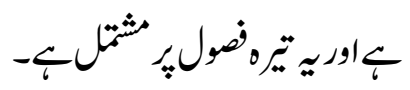

"Menachot describe the various grain based offering in the temple"53

\section{Hullin or chullin-3}

“Ordinary or Mundane”

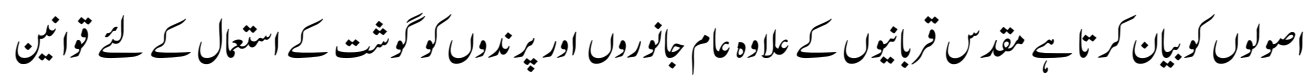

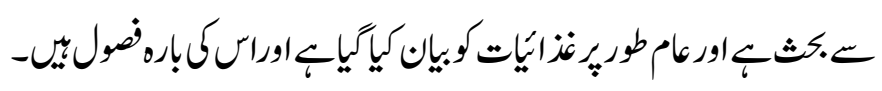

"Chullin describe the law of slaughter and meat consumption animals used for everyday as opposed to sacred reasons" 54 


\section{(الابكار):Bekhorot_4}

“ Firstborns”

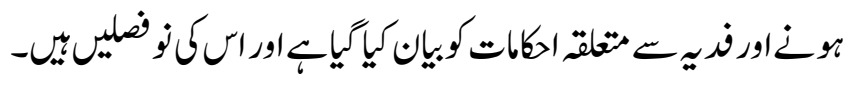

"Bekhorot describe the sanctification and redemption of animals and human first born" 55

\section{Arakhin_5}

"Dedications or Estimations”

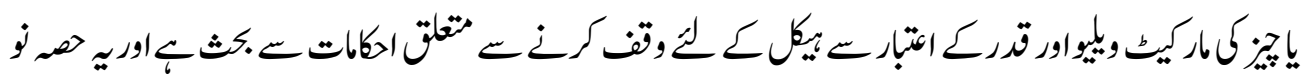

"Arakhin describe a person dedicating their value to the temple or dedicating a field" 56

تموراه:(البل الوض) Temurah-6

"Exchange”

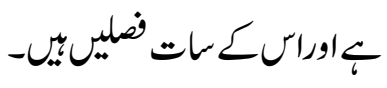

"Temurah discusses the law of happens if an animal is substituted for an animals dedicated for a sacrifice" 57

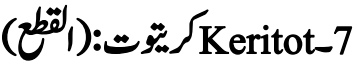

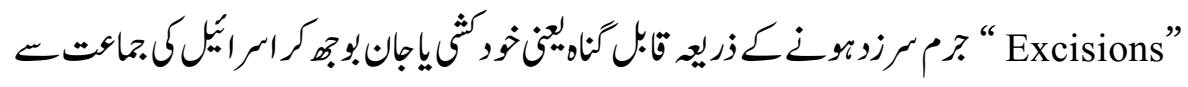

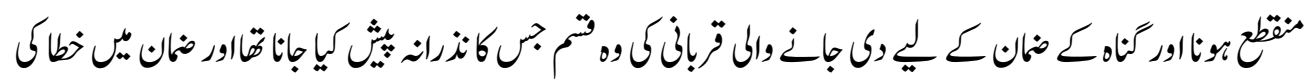

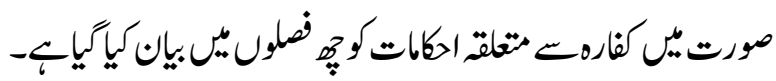
"Keritot describe the commandments for which the penalty is karet as well as sacrifices associated with their transgression" 58

\section{Me'ilah-8}

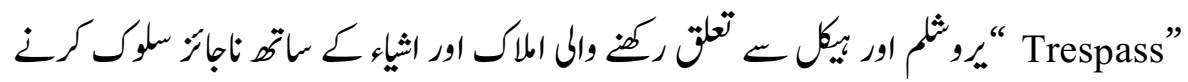

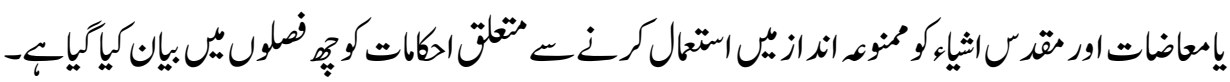


"Meilah the law of temple in Jerusalem also known as law of the misappropriation59"

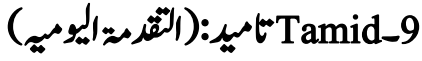

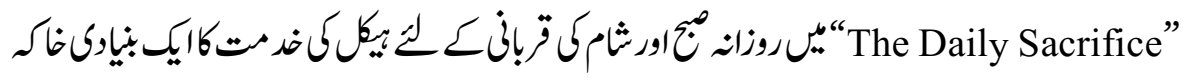

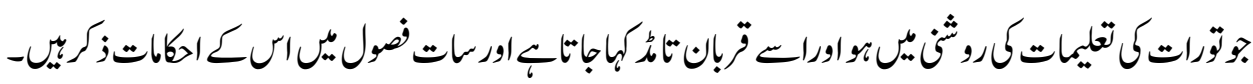

"Tamid describe the procedure of the tamid (Daily

Sacrifice)"60

ميروت:(المقاشيي)Middot-10

“" "Measurements”

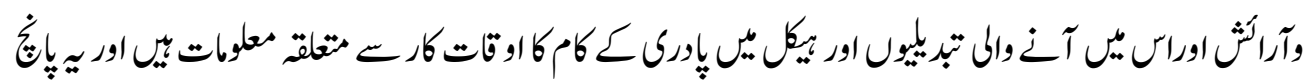

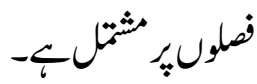

"Middott describe the measurements of the second temple"61

$$
\begin{aligned}
& \text { Kinnim-11 }
\end{aligned}
$$

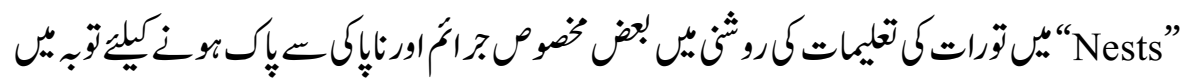

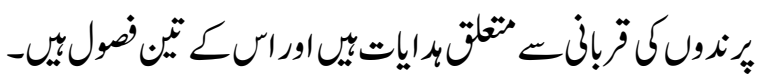

"Kinnim describe the complex law for situations where the mixing of bird offerings occurred" 62

\section{(Purities)(إطباروت:Tohorot-1}

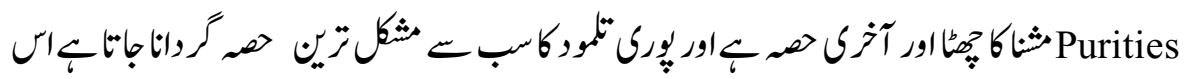

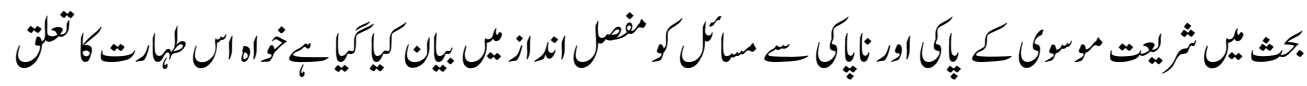

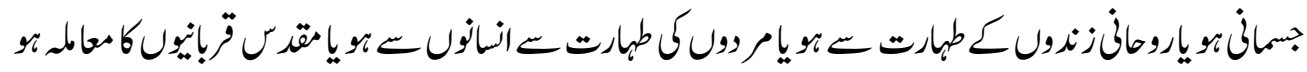

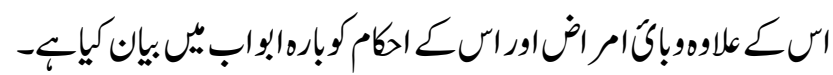

"Tohorot, "Purifications which discuss ritual purity of everything from food to persons"63

Keilim-1

“Vessels”

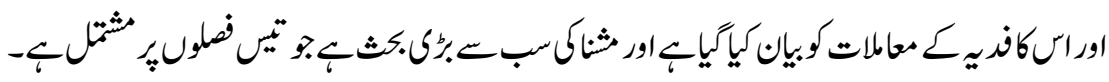


"The purities describe a large array of various utensils and how they fare in term of purity" 64

(اومالوت:ماتخيام)

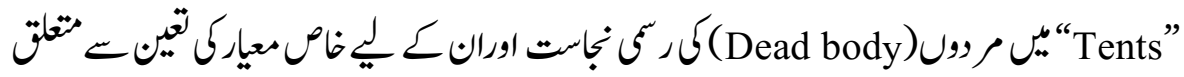

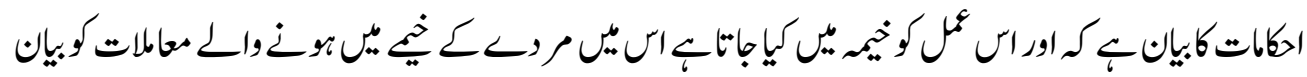

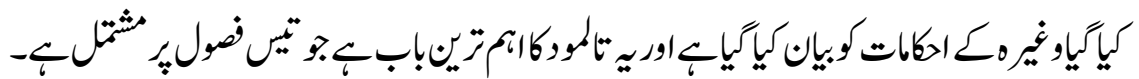

"Tents describe with the ritual impurity conveyed by a corpse (or parts of it) either through physical contactor through being under a common roof" 65

\section{نجا عeمa'im-3}

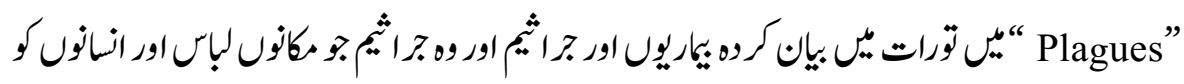

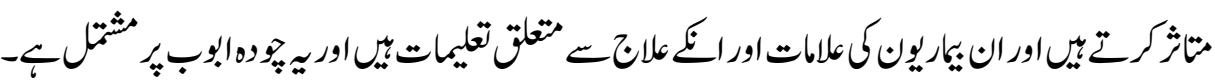

"Negaim describe scaly disease that can inflict a person's skin clothes and home this tractate explain tesa laws"66

(باراه(البقرة)Parah_4

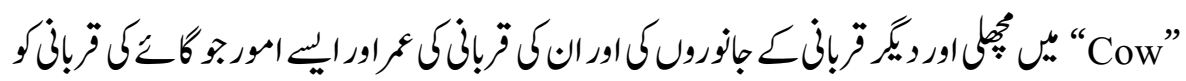

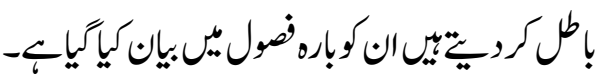

"Parah describe the laws of the Red heifer, A heifer mean cow no more the one year old" 67

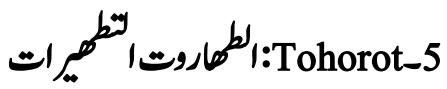

"Purities”

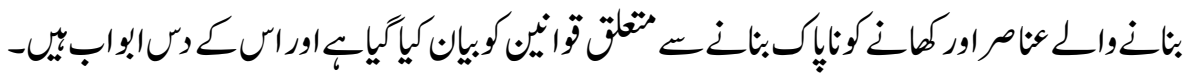
"Purities define the miscellaneous laws of purity, especially the actual mechanics of contracting impurity and the law of the impurity of food" 68

مثناؤت:المطام

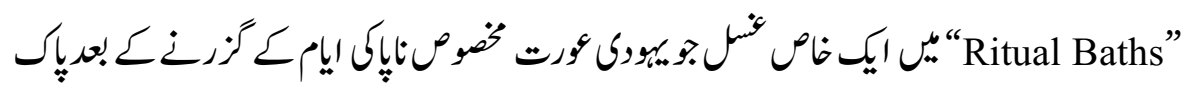

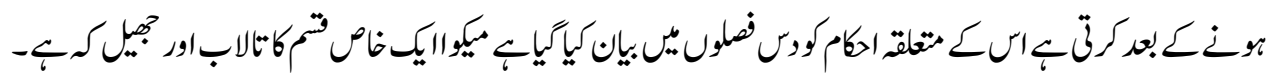


"Mikva,ot the Jewish ritual bath, and immerse herself undressed, so as to ritually purify her body" 69

(1):Niddah-7

"Separation”

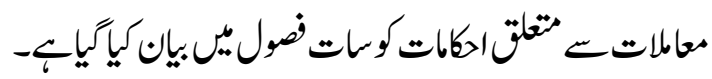

"Niddah describe a women either during her menstrual cycle or shortly after having given birth"70

\section{Makhshirin_8}

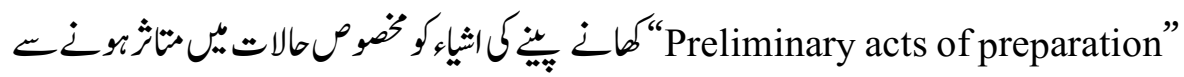

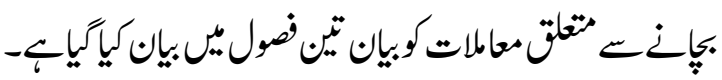

"Makhshirin describe liquids that make food susceptible to tumah(impurity)"71

\section{زابان:(السيان)Zavim-9}

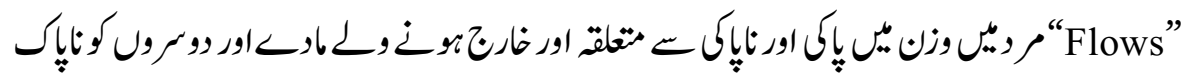

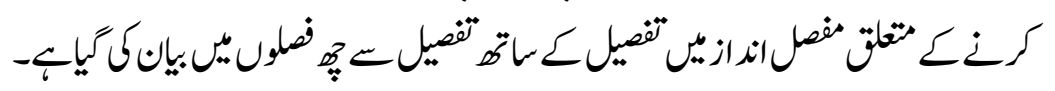

"Flows describe the law of a person who has ejaculated"72

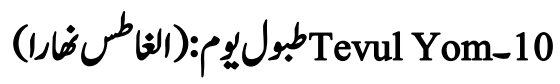

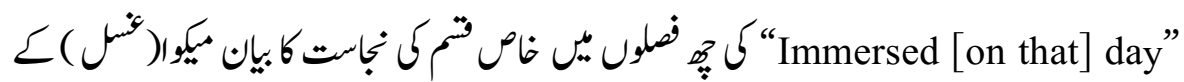

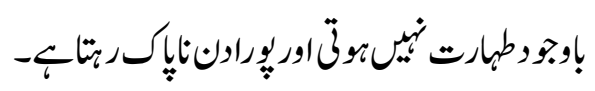

"Tevul Yom discusses a special kind of impurity where the person immerses in mikveh but is still unclean for rest of the day"73

\section{بيرام:(اليران) Yadayim-11}

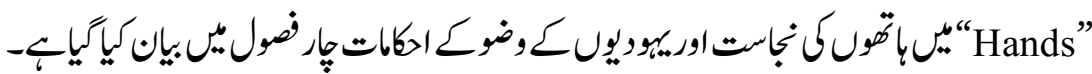

"The HEBREW term netillat yedayim refers to the actof ritually washing one's hands prior to eating bread. The TALMUD mandates this practice tocleanse the hands from any ritual impurity"74 


\section{Uktzim-12}

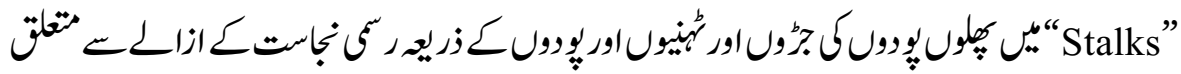

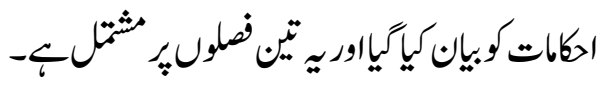

"Stalks describe the impurity of the stalks of fruit" 75

ثتيج بكث:

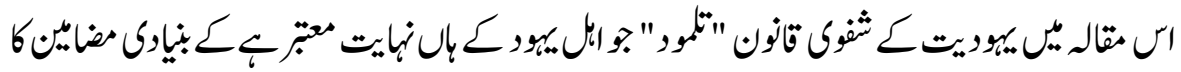

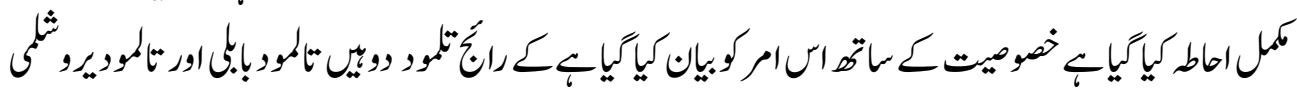

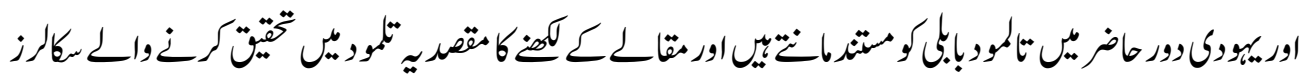

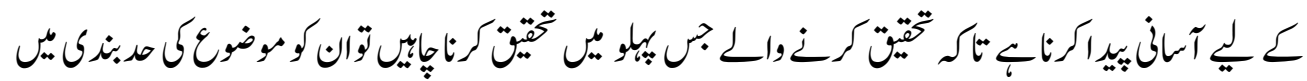

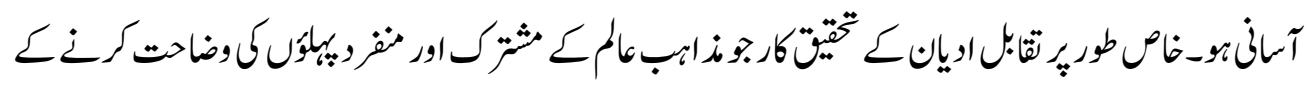

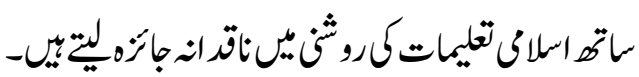




\section{والرجات}

${ }^{1}$ Britannica Concise Encyclopedia, the university of Chicago,2006,p 1267

${ }^{2}$ Encyclopedia Of Judaism,2006,p.15, Sara E. Karesh , Mitchell M. Hurvitz

${ }^{3}$ Britannica Concise Encyclopedia, the university of Chicago,2006,p 1867

${ }^{4}$ MICHAEL L. RODKINSON, The Babylonian Talmud,1918,p.3225

${ }^{5}$ Shema, the central confession of Judaism, on his lips>BarryW Holtz, Rabbi

Akiva ,Sage of Talmud, yale university press new haven and London,p.16

${ }^{6}$ Michael L, The Babylonian Talmud,p236

${ }^{7}$ The Amidah (literally the "standing," for the position in which it is recited) is the central prayer sequence of every Jewish worship service> Encyclopedia Of Judaism,2006,p.19

${ }^{8}$ Michael L, The Babylonian Talmud,p754

${ }^{9}$ Encyclopedia Of Judaism,2006,p.521

12 Terumah is also called gifts to the priest > Michael L, The Babylonian Talmud,p1971

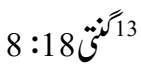

$$
\begin{aligned}
& \text { 14 1ايضا81: } 21 \\
& \text { 15 استثاه14: } 22
\end{aligned}
$$

${ }^{16}$ E. L. Ehrlich, The Jerusalem Talmud, Walter De Gruyter, Berlin , New york :2000,p.33

${ }^{17}$ Ibid.p. 33 
${ }^{18}$ Ibid.p.33

${ }^{19}$ Michael L, The Babylonian Talmud,p21

${ }^{20}$ Encyclopedia Of Judaism, p.463

${ }^{21}$ Ibid. p. 143

22 If a paschal sacrifice had been slaughtered for a woman living in her husband 's house, by her husband, and another lamb had been slaughtered by her father> MICHAEL L, The Babylonian Talmud,p1408

${ }^{23}$ The shekel was a unit of weight used for payment in gold and silver in the TANAKH, the Hebrew Bible. In pre-exilic Judaism, half-shekels and quarter shekels are mentioned > Encyclopedia Of Judaism, p.471

${ }^{24}$ Yom Kippur, Jews are barred from celebrating, eating, drinking, bathing, and sex on this day>Ibid:p.566

${ }^{25}$ Sukkot is the Hebrew word for "huts" or "booths" the holiday of Sukkot is thus often called in English

the Festival of Booths Sukkot is celebrated each year on the 15th day of Tishri, the seventh Jewish month >Ibid:p,502

${ }^{26}$ Yom Tov suchas : טירחא יתירא, avoiding excessive exertion; עובדא דחול, distinguishing Shabbat from workdays; and מוקצה, keeping a protective distance from the performance of forbidden labor.> Rabbi Daniel S. Nevins, Committee on Jewish Law and Standards,2012

${ }^{27}$ Encyclopedia Of Judaism, p.431

${ }^{28}$ Michael L, The Babylonian Talmud,p.2611

${ }^{29}$ Encyclopedia Of Judaism, p.409

${ }^{30}$ Michael L, The Babylonian Talmud,p.1950

${ }^{31}$ Ibid.p.2695

${ }^{32}$ Encyclopedia Of Judaism, p.332 
${ }^{34}$ Encyclopedia Of Judaism, p.270

${ }^{35}$ Ibid.p. 544

${ }^{37}$ Michael L, The Babylonian Talmud,p.4475

${ }^{38}$ Encyclopedia Of Judaism, p. 175

${ }^{39}$ Ibid.p.310

${ }^{40}$ Ibid.p. 371

${ }^{41}$ Michael L, The Babylonian Talmud,p.2666

${ }^{42}$ Ibid.p.333

${ }^{43}$ Ibid.p.394

${ }^{44}$ Ibid.p. 445

${ }^{45}$ Ibid.p. 2980

${ }^{46}$ Ibid.p. 3123

${ }^{47}$ Ibid.p. 3158

${ }^{48}$ Ibid.p.3158

${ }^{49}$ Encyclopedia Of Judaism, p. 185

${ }^{50}$ Michael L, The Babylonian Talmud,p.3235

${ }^{51}$ Encyclopedia Of Judaism, p.332

${ }^{52}$ Michael L, The Babylonian Talmud,p.3135

${ }^{53}$ Ibid.p. 1127

${ }^{54}$ Ibid.p. 2200

${ }^{55}$ Ibid.p.3007

${ }^{56}$ Ibid.p. 1669

${ }^{57}$ Ibid.p. 1734 
${ }^{58}$ Ibid.p. 1767

${ }^{59}$ Ibid.p. 1734

${ }^{60}$ Ibid.p. 1775

${ }^{61}$ Ibid.p.3159

${ }^{62}$ Ibid.p. 2584

${ }^{63}$ Encyclopedia Of Judaism, p.332

${ }^{64}$ Michael L, The Babylonian Talmud,p.505

${ }^{65}$ H.L. Strack, Introduction to the Talmud and Midrash , 1945

${ }^{66}$ MICHAEL L, The Babylonian Talmud,p.1866

${ }^{67}$ Ibid.p. 1498

${ }^{68}$ Ibid.p. 1523

${ }^{69}$ Encyclopedia Of Judaism, p.509

${ }^{70}$ Michael L, The Babylonian Talmud,p.2738

${ }^{71}$ Ibid.p. 2876

72 Ibid.p. 2903

${ }^{73}$ Ibid.p 2924

${ }^{74}$ Encyclopedia Of Judaism, p.355

${ }^{75}$ Michael L, The Babylonian Talmud,p.2783 